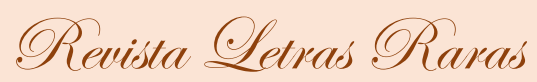

ISSN: 2317-2347 - Vol. 4, Anם 4, №2 - 2015

\title{
EDITORIAL
}

\section{Caríssimo leitor,}

Nesta segunda edição do ano de 2015, em um novo número, a Revista Letras Raras tem a grande alegria de partilhar um dossiê que dá espaço aos Estudos de Língua Inglesa. Como já é nosso procedimento, também damos lugar aos artigos de temáticas distintas da proposta pelo dossiê, além de também dar sítio aos textos de criação, isto é, textos que não têm o foco acadêmico-científico, mas que atendem à demanda criativa de muitos profissionais de Letras e da Linguagem.

Este número traz, além de nove artigos sobre a temática do dossiê, mais dois artigos na sessão Atemáticos. Mais uma vez, temos uma representativa participação de pesquisadores doutores, mestres, graduados e estudantes de graduação, de universidades todo o Brasil, tanto no que concerne à temática livre, quanto ao dossiê, assim como também a participação de um pesquisador de fora do país.

Ao iniciar o seu passeio pelas páginas eletrônicas, o leitor estará diante de uma significativa quantidade de reflexões que têm seu cerne na formação de professores da língua inglesa. Em Formação de professores de língua estrangeira $x$ ensino intercultural - um desafio a ser superado nas Letras, por exemplo, Vanessa Maria da Silva discute a questão da interculturalidade nesse âmbito, procurando analisar, por meio de um estudo documental, como os Cursos de Letras de conceituadas universidades do estado de São Paulo preparam seu estudante, futuro professor, para reafirmar e desenvolver as propostas idealizadas pelos pesquisadores e teóricos que contemplam ensino de língua indissociável do ensino da cultura. Já no texto Processos de subjetivação de professores de inglês na contemporaneidade, Ana Júlia Monteiro de Assis e Marco Antônio Margarido Costa estudam a discursividade em torno da formação de professores de inglês, buscando compreender quais discursos se mostram de forma mais evidente nos processos de subjetivação e que consequências trazem para a formação docente e para constituição de suas identidades. Ressalte-se que tal artigo resulta de uma pesquisa PIBIC-CNPq que investigou os processos de subjetivação de professores de inglês na contemporaneidade, à luz da Análise de Discurso de orientação pecheutiana e de sua vertente brasileira, desenvolvida inicialmente por Orlandi. Na continuidade e ainda dentro do mesmo viés, Daniela Aparecida Vendramini Zanella e Maria Angélica Lauretti Carneiro discutem sobre a Produção de significados na atividade de formação do PIBID/UNISO de língua inglesa. Nesse artigo, as autoras buscam registrar a experiência dos educadores atuantes no projeto e constatar se o grupo produz significados acerca dele e ainda quais seriam esses significados. Esse instigante estudo está ancorado na teoria da atividade sócio-histórico-cultural e em questões de linguagem em uma perspectiva dialógica. As autoras desenvolveram a análise com suporte em excertos advindos das experiências dos educadores e embasada pelo aporte teórico-metodológico da pesquisa crítico-colaborativa. 


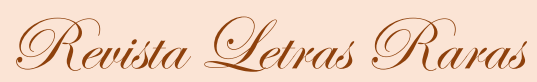

ISSN: 2317-2347 - Vol. 7, Ano 4, №2 - 2015

Na sequência, em Sobre o ensino da língua inglesa no currículo escolar por repercussões do Programa Ciência sem Fronteiras, Eliana Santiago Gonçalves Edmundo e José Marcelo Freitas de Luna trazem a problemática sobre o fato de que a ausência de proficiência na língua inglesa pode ser um significativo obstáculo para a participação de estudantes brasileiros no Programa Ciências sem Fronteiras. Os autores desenvolveram a discussão a partir de reportagens da mídia digital dos últimos três anos e de dispositivos legais que normatizam o ensino de língua estrangeira na educação básica. Ressaltam o descompasso entre o status da língua inglesa frente às demandas de internacionalização do ensino superior no país e o estatuto desse idioma expresso nas políticas públicas educacionais para a educação básica brasileira. Ainda no âmbito da internacionalização, Sílvia Ramos-Sollai apresenta uma importante colaboração concernente ao biletramento. O elo lar-comunidade-escola nos programas de biletramento inglês-português nos estados unidos apresenta um levantamento que ressalta a influência do lar, da comunidade e da escola na manutenção da língua e cultura minoritárias em crianças matriculadas em programas de biletramento em comunidades de imigrantes nos Estados Unidos. Para tal levantamento, a autora faz uma descrição dos programas e um relato histórico e a legislação vigente do sistema escolar. Destaca a construção constante de uma identidade bicultural para suportar o biletramento e também lembra da necessidade de práticas culturais e sociais em mais de uma língua por todos envolvidos, para que a estrutura e o investimento bilíngue se sustente por médio a longo prazo.

Considerando-se indispensável a questão cultural na globalização, incidindo diretamente na questão identitária, Maurício Demichelli traça ponderações sobre a Cultura, identidade e globalismo. Parte de diferentes concepções de cultura e suas relações sócio-políticas, chegando a conceitos que a relaciona com estruturas de biopoder e ainda traz conceitos de cultura, identidade e transculturação, analisando suas relações e implicaturas em um mundo global, onde culturas, línguas e identidades estão em constante contato. $\mathrm{O}$ autor revela os efeitos do cruzamento cultural e propõe uma percepção positiva no âmbito da transculturação, relacionado ao trabalho dos profissionais que têm como objeto a língua inglesa.

Nas linhas da literatura, Rusanil dos Santos Moreira Júniore Laureny Lourenço examinam em $A$ identificação do sujeito pós-moderno na literatura contemporânea de Markus Zusak: análise das personagens de Cartas Cruzadas, o caráter pós-moderno da obra australiana Cartas Cruzadas, de Markus Zusak, posto que tal obra apresenta questões pertinentes à contemporaneidade e, em especial, à configuração do sujeito pósmoderno, principal objeto de estudo dos autores deste artigo. Colocam em destaque que em Cartas Cruzadas, o protagonista Ed Kennedy é submetido a missões em que, na realização delas, é possível compreender a caracterização do pós-moderno na sociedade contemporânea, além de identificar elementos peculiares ao pós-modernismo. Ainda nas trilhas literárias, Jenison Alisson dos Santos, Caio Antônio de Medeiros Nóbrega Nunes Gomes e Elisa Mariana de Medeiros Nóbrega apresentam On Booze: a representation of the roaring twenties in the Great Gatsby. Destacam que a obra prima 
de F. Scott Fitzgerald, O grande Gatsby (2001), enfoca a representação e a crítica do contexto histórico no qual autor e obra estão inseridos. Os autores lembram o leitor que Fitzgerald é considerado o porta-voz da década de 1920, período do pós Primeira Guerra Mundial e que oferece aos seus leitores uma visão distinta da Era de Ouro dos Estados Unidos da América. Assim, argumentam e analisam a temática, buscando produzir um diálogo pertinente com a obra de Fitzgerald.

Fechando o dossiê de estudos de Língua Inglesa, Ana Laura Hoffart e Daniela Vendramini trazem reflexões sobre A produção de significados na elaboração escrita em língua inglesa na atividade social: participação de Pen- pal, objetivando analisar a produção de significados na elaboração escrita em língua inglesa dos alunos de uma escola pública a partir do desenvolvimento de atividades criadas por uma educadora no PIBID-LI/UNISO. Esse estudo está ancorado em conceitos sobre o ensino-aprendizagem de língua inglesa por meio de Atividade Social e o brincar, na concepção vygotskyana. Os resultados apontam para as dificuldades enfrentadas, além da produção de significados e da importância dos instrumentos multimodais para tornar o estudo da língua inglesa atrativo.

Na sessão Atemática, dois textos são apresentados: Literaturas africanas de expressão portuguesa: algumas considerações sobre as literaturas angolana $e$ moçambicana, de Marcela de Melo Cordeiro Eulálio e Alain-Philippe Durand e também Da abordagem comunicativa à perspectiva acional no Curso de Letras Português / Francês da Universidade Federal de Sergipe, de autoria de Weslin de Jesus Santos Castro e Renilson Santos Oliveira. Em ambos artigos, é possível encontrar questões determinantes para as discussões tanto no domínio da literatura africana, quanto do ensino da língua francesa. Concluindo este número, na sessão de Criação, encontramos um Discurso de colação de grau proferido Josimar Alves da Silva, agora, profissional graduado em Letras, da Universidade de Campina Grande.

Assim, caro leitor, partilhemos, pois, as leituras destas páginas.

Profa. Dra. Renata Philippov

Profa. Dra. Vera Harabagi Hanna

Coordenadora do dossiê Estudos sobre da língua inglesa: ensino e outras perspectivas

Profa. Dra. Josilene Pinheiro-Mariz

Editora-Geral da Revista Letras Raras 